\title{
PREDATORY PRICING: SINGLE- FIRM DOMINANCE, EXCLUSIONARY ABUSE AND PREDATORY PRICES (PART 2)
}

\author{
Jan Louis van Tonder \\ LLB LLM LLM \\ Postgraduate Certificate, Competition Law \\ Postgraduate Diploma, EU Competition Law \\ Postgraduate Diploma, Economics for Competition \\ Law \\ Research Associate, Faculty of Law, Mercantile \\ Law Department, Nelson Mandela University \\ Attorney and Conveyancer of the High Court of \\ South Africa \\ Solicitor of the Senior Courts of England and \\ Wales
}

\section{SUMMARY}

Important pronouncements of legal principle were recently made by the Competition Appeal Court and Constitutional Court on the determination of predatory pricing under section 8 of the Competition Act 89 of 1998. These pronouncements must now be seen in the context of the subsequent commencement of certain provisions of the Competition Amendment Act 18 of 2018, which affect predatory pricing cases under section 8 of the Act. In light of these developments, the main aim of this series of three articles is to evaluate the law relating to the economic concept of predatory pricing under the Competition Act. In this context, the main constituent elements of a predatory pricing case - namely dominance, identifying an exclusionary abuse, and predatory prices - are discussed in three parts. Part 1 has critically evaluated the law on the determination of single-firm dominance under section 7 of the Competition Act. Part 2 starts to focus on the abuse analysis and discusses the basic forms of abuse, the meaning of abuse, tests that have been developed to identify exclusionary abuse, the criticism of the traditional theory of predatory pricing, the main strategic economic theories of predatory pricing and non-pricing theories of predation. Part 3 then specifically deals with the law of predatory prices under section $8(c)$ and (d)(iv) of the Competition Act. Pursuant to section 1(3) of the Competition Act, when interpreting or applying the Competition Act, appropriate foreign and international law may be considered. This is complementary to section $1(2)(a)$, which directs that the Competition Act must be interpreted in a manner that is consistent with the Constitution and gives effect to the purposes set out in section 2. In light hereof, where appropriate, the South African position is mainly compared with the position in the European Union and the United States. 


\section{INTRODUCTION}

In light of the Media24 case,${ }^{1}$ in which several important pronouncements of legal principle were made, as well the subsequent commencement of certain provisions of the Competition Amendment Act 18 of 2018, the aim of this series of three articles is to evaluate the law and elements relating to the economic concept of predatory pricing under the Competition Act 89 of 1998 (the Act). Part 1 has critically evaluated the law on the determination of single-firm dominance under section 7 of the Act. If a firm is found to be dominant under section 7 of the Act, it must then be determined whether the conduct in question is prohibited by the abuse-of-dominance provisions under section 8. The abuse provisions are aimed at preventing anticompetitive harm caused by the unilateral exclusionary conduct of a dominant firm. Harm means a loss to consumer welfare, but also includes certain macro-economic considerations as well as broader public-interest goals. ${ }^{2}$ In the context of the abuse analysis, predatory pricing is considered to be an exclusionary abuse. The general concept of an abuse, its meaning and, the different standards used to identify an exclusionary abuse, present many issues, some of which are not settled. Thus, the main focus of Part 2 is on these issues. The main theories of predation are also considered. Part 3 then specifically deals with the law of predatory prices under section $8(c)$ and (d) (iv) of the Act.

Heading 2 of this article provides a brief overview of the structure of section 8 of the Act in order to show under which sub-sections of that provision an allegation of predatory pricing may fall. In order to distinguish an exploitative abuse from an exclusionary abuse, heading 3 discusses the basic forms of abuse and the meaning of an abuse. Heading 4 builds on this latter section by examining the various standards relevant to identifying exclusionary conduct. The main aim of this section is to assess the elements of these standards and, for purposes of identifying predatory pricing as a form of exclusionary conduct, some of the pros and cons of these tests - not their consistency with the existing cost benchmarks and case law. Heading 5 discusses the criticism of the traditional theory of predatory pricing, the main strategic economic theories of predatory pricing and non-pricing theories of predation. Heading 6 provides a conclusion.

\section{BASIC STRUCTURE OF SECTION 8}

Paragraphs (a) and $(b)$ of section 8 of the Act prohibit, respectively, excessive pricing and refusal to grant access to an essential facility. These two provisions are often referred to as per se prohibitions.

\footnotetext{
1 Competition Commission of South Africa v Media 24 (Pty) Limited [2019] ZACC 26; Media 24 Proprietary Limited $v$ Competition Commission of South Africa 146/CAC/Sep16 and Competition Commission of South Africa v Media Limited CT 013938/CR154Oct11.

$2 \mathrm{~S} 2$ of the Competition Act.
} 
Section $8(d)$ lists six specific types ${ }^{3}$ of prohibited exclusionary act. Predatory pricing, and the other specific types of exclusionary act, are prohibited if the complainant can show that the act in question had an anticompetitive effect and if the respondent fails to show that the act resulted in technological, efficiency or other pro-competitive gains that outweigh the anti-competitive effect of its act.

Section $8(c)$ refers generally to an "exclusionary act". Accordingly, this section prohibits all those exclusionary acts (including predatory pricing allegations that are not specifically listed in section $8(d)$ ), but only if the complainant shows that the anti-competitive effect of the act in question outweighs any technological, efficiency or other pro-competitive gain shown by the respondent.

Paragraphs $(c)$ and $(d)$ of section 8 are both said to be rule-of-reason prohibitions.

\section{BASIC FORMS AND MEANING OF ABUSE}

\section{Basic forms of abuse}

As discussed, the Act specifically regulates the behaviour of dominant firms to ensure that they are not abusing their dominant positions to the detriment of competition and consumers. ${ }^{4}$ Broadly speaking, two main forms of abusive behaviour by dominant firms under section 8 of the Act have been distinguished. One category relates to exploitative abuse, which concerns pricing and other practices ${ }^{5}$ that result in direct harm to consumers. ${ }^{6}$ Another category relates to exclusionary abuse, which is perhaps, to date, the more common and important category of abuse.

Exclusionary abuses concern strategic conduct by dominant firms directed against competitors that indirectly cause a loss to consumer welfare. ${ }^{7}$ The conduct is exclusionary in the sense that it unlawfully excludes or forecloses the competitors' production, participation or growth in the market. If the competitors are sufficiently important for the functioning of competition in the market and the exclusion or foreclosure is significant enough, this will lead to the creation, enhancement or maintenance of the dominant firm's ability to exercise market power. In turn, this will have the effect of distorting competition in the market for the end-consumers and can therefore adversely affect consumer welfare. Since legitimate competition that excludes competitors is a crucial element of consumer welfare maximisation, the main element is the loss to consumer welfare.

3 These are: requiring or inducement not to deal; refusal to supply scarce goods or services to a competitor or customer; tying or bundling; predatory pricing; buying up a scarce supply of intermediate goods or resources required by a competitor; and margin squeeze.

4 Competition Commission of South Africa v Media 24 (Pty) Limited supra par 31 and 59.

5 For example, monopsony purchasing power (abuse of buyer power) and abusive or "unfair" contractual clauses.

6 S 8(a) of the Consumer Act states that "it is prohibited for a dominant firm to charge an excessive price to the detriment of consumers".

7 Competition Commission of South Africa v Media 24 (Pty) Limited supra par 59; s 8(c) and (d) prohibit examples of this kind of conduct. 
This means that not every exclusionary effect is necessarily detrimental to competition; the function of section 8 is not to protect competitors that are less efficient than the dominant firm.

Predatory pricing is an example of conduct that can be considered to be an exclusionary abuse under both paragraphs $(c)$ and $(d)$ (iv) of section 8.

\section{Meaning of abuse}

A central issue that competition law and policy seek to address is how to discriminate between unilateral conduct that is deemed to be normal competition or competition on the merits, and unilateral conduct that is anticompetitive. Only the latter should be considered unlawful. However, dominant firms that are efficient may be able to exclude or foreclose competitors from the market (or from parts of the market) by competition on the merits as well as by anti-competitive conduct. This means that commercial behaviour by firms with market power can appear to be both anti-competitive and pro-competitive at the same time. Antitrust jurisdictions around the world have found it hard to create administrable legal rules and precedents that are good at discriminating between competition on the merits and anti-competitive conduct.

The Act does not define what an "abuse" is. An essential element of a section $8(c)$ or $8(d)$ case is proof that the dominant firm has engaged in an "exclusionary act". Building on the basic forms of abuse, the Act defines an "exclusionary act" as an act that impedes or prevents a firm from entering into, participating in or expanding within a market. ${ }^{8}$ In turn, "participate" refers to the ability of or opportunity for firms to sustain themselves in the market. ${ }^{9}$ A reading of these two elements together means that the definition of an act that may be considered to be an (exclusionary) abuse is broad and does not provide much insight into how to discriminate between conduct that is competitive or anti-competitive. The definition seems mainly to focus on the nature of the conduct under consideration, which makes it hard to follow. ${ }^{10}$

In Patensie Sitrus Beherend Beperk $v$ Competition Commission, ${ }^{11}$ the Competition Appeal Court, in considering whether an exclusionary abuse had been committed, referred to the decision of the European Court of Justice in Hoffmann-La Roche \& Co. AG v Commission, ${ }^{12}$ which it quoted in part as follows:

"The concept of abuse is an objective concept relating to the behaviour of an undertaking in a dominant position which is such as to influence the structure of the market where, as a result of the very presence of the undertaking in question, the degree of competition is weakened and which, through methods different from those which condition normal competition in products or services on the basis of the transactions of commercial operators, has the

S 1(1) of the Competition Act.

Ibid.

10 Sutherland and Kemp Competition Law of South Africa Issue 21 (2017) 7-80.

[2003] 2 CPLR 247 (CAC) 264-265.

12 Case 85/76 Hoffmann-La Roche \& Co. AG v Commission of the European Communities [1979] ECR 461 par 91. 
effect of hindering the maintenance of the degree of competition still existing in the market or the growth of that competition."

This definition is usually the starting point for the assessment of alleged exclusionary conduct under European Union (EU) competition law - that is, practices of a dominant firm that supposedly have an adverse effect on the process of competition. ${ }^{13}$ While this legal definition also appears hard to follow, its formulation indicates that abusive conduct is likely to influence the structure of the market, weaken the existing degree of competition in the market, and involves the dominant firm having recourse to methods different from those governing normal competition.

Other definitions of abuse have also been put forward - for instance, anything that is not legitimate competition or competition on the merits, ${ }^{14}$ conduct that lacks an objective economic justification, ${ }^{15}$ or conduct that has the effect of causing harm to consumers. ${ }^{16}$ There is a great deal of uncertainty surrounding all these formulations, including what the definition of an exclusionary abuse is or should be ${ }^{17}$ However, the importance of the definition in Hoffmann-La Roche \& Co. AG v Commission is its emphasis on the need to analyse the effect of the conduct in order to establish an abuse..$^{18}$ It is important to focus on the negative effect that the conduct has on competition and the structure of the market rather than any potentially more transient behavioural effects. ${ }^{19}$ In line with these arguments, later on in the Patensie Sitrus Beherend Beperk v Competition Commission decision, the Competition Appeal Court noted that the effect of offending conduct was to hinder the maintenance of the degree of competition that exists and to hinder the growth of competition. ${ }^{20}$

\section{ASSESSING EFFECTS: GENERAL STANDARDS FOR IDENTIFYING EXCLUSIONARY CONDUCT}

It can be seen that the nature of the definition of what conduct constitutes an "exclusionary act" is uncertain and vague. In this light, progression has been made by antitrust experts to help identify when dominant firm behaviour is unlawfully exclusionary, as distinct from being competition on the merits. ${ }^{21}$ In particular, several economic tests have been advanced to distinguish anti-

3 Bellamy and Child European Union Law of Competition 8ed (2018) 894.

14 Case IV/30.698 ECS/AKZO, European Commission Decision of 14 December 1985, OJ L374/1 par 81 upheld on appeal in Case C-62/86 AKZO Chemie BV v Commission of the European Communities [1991] ECR I-03359.

15 T-203/01 Manufacture française des pneumatiques Michelin v Commission of the European Communities [2003] ECR II-04071 par 107 and 110.

16 Case C-209/10 Post Danmark A/S v Konkurrencerådet EU:C:2012:172 par 24.

17 See further O'Donoghue and Padilla Law and Economics of Article 102 TFEU 2ed (2013) 217-220, where the authors write about the various difficulties of the definition of an abuse and fn 20 where the authors refer to noteworthy publications on the issue.

18 Bellamy and Child European Union Law of Competition 894.

19 Ibid.

20 Patensie Sitrus Beherend Beperk v Competition Commission supra 264-265.

21 Generally, see Elhauge "Defining Better Monopolization Standards" 200356 Stanford Law Review 253; Vickers "Abuse of Market Power" 2005 115(504) The Economic Journal F244 Werden "Identifying Exclusionary Conduct Under Section 2: The 'No Economic Sense Test" 2006 73(2) Antitrust Law Journal 413. 
competitive conduct from competition on the merits. These tests include the profit-sacrifice test, the no-economic-sense test as a variant of the profitsacrifice test, the equally-efficient-competitor test (or as-efficient-competitor test) and the consumer-welfare test. In principle, predatory pricing in its most basic form can satisfy all these tests or principles.

\section{The profit-sacrifice test}

Generally, the profit-sacrifice test asks whether the conduct in question is more profitable in the short term than any other conduct the dominant firm could have engaged in that did not have the same (or greater) exclusionary effect. $^{22}$ If the conduct is not more profitable, the short-term sacrifice of profits might have been an investment in an exclusionary scheme, whereby the dominant firm seeks to strengthen or maintain market power and recoup the foregone profits in the future. Therefore, the exclusionary conduct requires the dominant firm deliberately to forego profits or incur losses in the short term, so as to impede or prevent one or more of its actual or potential competitors from entering into, participating in or expanding within the market, with a view to strengthening or maintaining its market power, thereby causing consumer harm.

In the context of predatory pricing and on a general level, this line of analysis is attractive. Predatory pricing involves a short-term sacrifice of profits in the expectation of greater profits in the future due to the exclusion or foreclosure of competitors. On a conceptual approach, it is also simpler to assess than consumer welfare. The test does not require the balancing of the conduct's ultimate effects on consumer welfare. Instead, the test focuses on the financials of the dominant firm.

However, there are significant practical difficulties with this test for purposes of using a profit sacrifice as an indicator of predatory pricing. ${ }^{23}$ First, there are legitimate commercial reasons why a firm may deliberately sacrifice profits in the short term other than to foreclose competitors. ${ }^{24}$ It is

22 According to Areeda and Turner ("Predatory Pricing and Related Practices Under Section 2 of the Sherman Act" 197588 Harvard Law Review 697 698), predation in any meaningful sense cannot exist unless there is a temporary sacrifice of net revenues in the expectation of greater future gains. Indeed, the classically feared case of predation has been the deliberate sacrifice of current profits for the purpose of driving rivals out of the market and then recouping the losses through higher profits earned in the absence of competition; see also, for example, Bork (The Antitrust Paradox: A Policy at War With Itself (1978) 156), who states that predation may be defined "as a firm's deliberate aggression against one or more rivals through the employment of business practices that would not be considered profit maximizing except for the expectation either that (1) rivals will be driven from the market, leaving the predator with a market share sufficient to command monopoly profits, or (2) rivals will be chastened sufficiently to abandon competitive behavior the predator finds inconvenient or threatening."; and Ordover and Willig ("An Economic Definition of Predation: Pricing and Product Innovation" 198191 Yale Law Journal 8 9-10), who state that predatory behaviour is "a response to a rival that sacrifices part of the profit that could be earned under competitive circumstances, were the rival to remain viable, in order to induce exit and gain consequent additional monopoly profit."

23 O'Donoghue and Padilla Law and Economics of Article 102 TFEU 227; Vickers 2005 The Economic Journal F244-F261; Salop "Exclusionary Conduct, Effect on Consumers, and the Flawed Profit-Sacrifice Standard” 200673 Antitrust Law Journal 311341.

24 Elhauge 2003 Stanford Law Review 253. 
also uncertain whether the profit-sacrifice test requires a firm to choose the most profitable commercial behaviour to avoid a finding of exclusionary conduct. Moreover, what is the alternative pricing policy? Is it feasible and, if so, how much profit would it generate? Secondly, it can be very difficult to assess whether a particular pricing strategy represents a profit sacrifice. For firms to assess for themselves whether their conduct is profit maximising is difficult and so they could easily fail to maximise profits by mistake, not by design. It is also unclear what degree of sacrifice is required to establish exclusionary conduct, or whether the rule is strict in that any profit sacrifice indicates abuse.

Despite its claimed objectivity, ${ }^{25}$ an assessment of profit sacrifice requires a consideration of how much profit a firm would make under a counterfactual situation where it maximised profits. This requires far more detailed information and sophisticated analysis than a competition authority can realistically carry out.

\section{The no-economic-sense test}

In response to these criticisms, the United States (US) has adopted variants of a test that is broadly called the no-economic-sense test. ${ }^{26}$ One version applies the no-economic-sense test by comparing the non-exclusionary profits from the conduct to the profits the firm would have earned from alternative, legal conduct in which it would have engaged (the "but-for" scenario). ${ }^{27}$ If the non-exclusionary profits would be greater, the conduct would make economic sense without exclusionary effects and thus be legal. If the non-exclusionary profits were lower, the conduct would not make economic sense and would thus potentially be unlawful.

Another version of the no-economic-sense test asks whether the conduct in question would make economic sense for the dominant firm to pursue save for its tendency to eliminate or lessen competition. ${ }^{28}$ As long as the conduct is profitable apart from its exclusionary effect, it would pass this version of the no-economic-sense test, regardless of whether any other conduct would have been more profitable or the extent of any harm to competition.

Both the profit-sacrifice and no-economic-sense tests seek to establish objective standards by which to identify conduct that is likely to damage the competitive process, as opposed to merely aggressive competition. By combining the usual test for profit sacrifice with the no-economic-sense test, other jurisdictions have been able to develop an approach to predatory pricing that ensures that only profit sacrifice that is undertaken exclusively to eliminate competitors is prohibited. However, although the no-economicsense test addresses some of the criticisms of the profit-sacrifice test, it is not completely free of criticism. ${ }^{29}$

\footnotetext{
Patterson "The Sacrifice of Profits in Non-Price Predation" 200318 Antitrust 37.

O'Donoghue and Padilla Law and Economics of Article 102 TFEU 230.

Werden 2006 Antitrust Law Journal 420-422.

See Verizon Communications Inc. v. Law Offices of Curtis V. Trinko LLP (2004) 540 US 398.

29 See O'Donoghue and Padilla Law and Economics of Article 102 TFEU 230.
} 


\section{The equally-efficient-competitor test}

Another practical approach, which was proposed by Posner, is to ask whether the conduct would exclude an equally efficient competitor or, stated differently, a competitor that is as efficient as the dominant firm. ${ }^{30}$ Posner's general standard for deciding exclusionary claims under US antitrust law proposes that the complainant must first prove that the respondent has monopoly power, and secondly that the challenged practice is likely in the circumstances to exclude from the respondent's market an equally (or more) efficient competitor. ${ }^{31}$ The respondent can rebut by proving that although it is a monopolist and the challenged practice exclusionary, the practice is, on balance, efficient. ${ }^{32}$ Although under the Competition Act the burden would be different, the test addresses some of the concerns with open-ended balancing by requiring that the complainant shows that the conduct in question is likely in the circumstances to exclude from the respondent's market an equally or more efficient competitor. ${ }^{33}$ This test is based on the underlying principle that "a firm should not be penalized for having lower costs than its rivals and pricing accordingly". ${ }^{34}$

The test has found acceptance in the US and the EU in predatory pricing cases (as well as in other pricing cases such as margin squeeze and certain types of bundling), particularly in discussions of how to identify a price as predatory. Posner's own examples in his proposal concern pricing practices. His view is that it would be absurd to require a firm to hold a price umbrella over less efficient entrants. ${ }^{35}$ Practices that will exclude only less efficient firms, such as the monopolist's dropping his price nearer to but not below its cost, should not be actionable, because efficiency should be encouraged. ${ }^{36}$ Under this standard of identifying exclusionary conduct, low-cost firms should not hold their prices above their costs simply to allow a competitor to become established in the market.

There is, however, criticism of the equally-efficient-competitor test. First, less efficient competitors would in theory be able to increase consumer welfare if the increased competition that their presence in the market creates outweighs their relative inefficiency. ${ }^{37}$ This is especially so in markets where competition is just starting to emerge and where it might be inappropriate to compare the efficiency of new competitors with that of the dominant firm. ${ }^{38}$ In

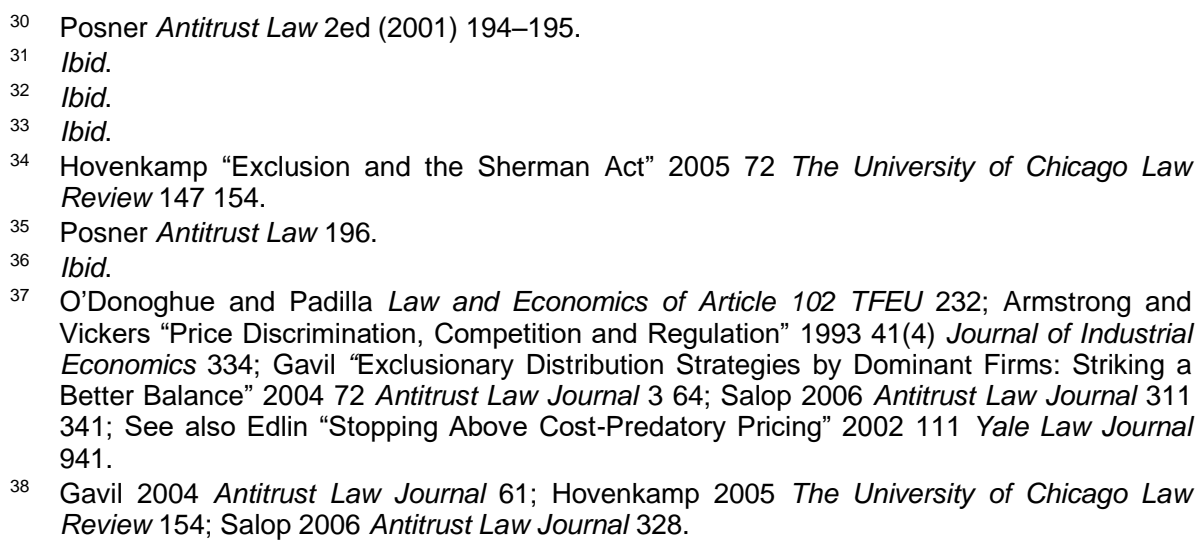

37 O'Donoghue and Padilla Law and Economics of Article 102 TFEU 232; Armstrong and Vickers "Price Discrimination, Competition and Regulation" 1993 41(4) Journal of Industrial Economics 334; Gavil "Exclusionary Distribution Strategies by Dominant Firms: Striking a Better Balance" 200472 Antitrust Law Journal 3 64; Salop 2006 Antitrust Law Journal 311 341; See also Edlin "Stopping Above Cost-Predatory Pricing" 2002111 Yale Law Journal 941.

38 Gavil 2004 Antitrust Law Journal 61; Hovenkamp 2005 The University of Chicago Law Review 154; Salop 2006 Antitrust Law Journal 328. 
the EU, this has led to an acceptance that the duty to protect firms from predation is not limited to protecting equally efficient firms, but also, in exceptional circumstances, less efficient firms. ${ }^{39}$ Another criticism of the test arises in cases where economies of scope and scale characterise the market, and competitors only compete for a limited contestable portion of that market. ${ }^{40}$ The European Commission seeks to overcome this obstacle by putting aside the advantages that the dominant firm derives from being an unavoidable competitor for a portion of the market and, instead, only focuses on equal efficiency for that portion of the market that is contestable. ${ }^{41}$

It is important that economies of scale exist and that legitimate competition on the merits not be prohibited. ${ }^{42}$ The protection of equally efficient firms only does not appear to be an immutable rule that must be applied in all investigations into potentially abusive pricing conduct. ${ }^{43}$ In terms of the definition of an "exclusionary act", there is no textual basis for mandating the protection of equally efficient competitors only. The definition speaks merely of "a firm" being actually or potentially impeded or prevented from entering into, participating in, or expanding within a market. Therefore, a firm (and not only an equally efficient firm) should not be unlawfully impeded or prevented from having an opportunity to sustain themselves in the market.

Further, in many industries the variable costs of large-scale production are cheaper than those associated with small-scale production. Here, new entrants are easily driven out of the market before they have had the opportunity to expand and reach their potential as an equally efficient competitor ${ }^{44}$ In markets that are already dominated by one or a few firms, new entry by firms is desirable, as is allowing them to grow into large-scale producers. ${ }^{45}$ In this context, the aims of the Act include giving small- and medium-sized enterprises an equitable opportunity to participate in the economy.

\section{The consumer-welfare test}

Given the objective of identifying conduct that causes harm to the competitive process, ${ }^{46}$ the consumer-welfare test focuses on the "overall impact on consumers" or net effects on consumer welfare. ${ }^{47}$ The idea is to identify exclusionary conduct of a dominant firm that has, or is likely to have,

\footnotetext{
O'Donoghue and Padilla Law and Economics of Article 102 TFEU 232.

Ibid.

41 European Commission Guidance on the Commission's enforcement priorities in applying Article 82 of the EC Treaty to abusive exclusionary conduct by dominant undertakings [2009] OJ C45/02 par 39-44; O'Donoghue and Padilla Law and Economics of Article 102 TFEU 233.

42 Competition Commission of South Africa v Media 24 (Pty) Limited supra par 111.

43 Ibid.

44 Bishop and Walker The Economics of EC Competition Law: Concepts, Application and Measurement 3ed (2010) 306.

45 Ibid.

$46 \mathrm{~S} 2$ of the Competition Act.

47 Salop 2006 Antitrust Law Journal 330.
} 
a material, adverse effect on consumer welfare. ${ }^{48}$ In particular, the test asks whether particular conduct reduces competition without creating a sufficient improvement in performance to fully offset these potential adverse effects on prices and thereby prevent consumer harm. At a fundamental level, the test entails quantifying and weighing the pro-competitive and anti-competitive effects of the challenged conduct. ${ }^{49}$ The test makes unlawful all conduct by which a dominant firm acquires or maintains market power where the conduct causes net harm to consumers. This is the type of competitiveeffects analysis contemplated in the merger provisions ${ }^{50}$ and has the advantage of focusing the identification of exclusionary conduct on the impact on consumers, a key concern of the Act. ${ }^{51}$

The test does, however, present a number of difficulties. It is unclear whether predatory pricing (as an exclusionary abuse under section 8) requires as a necessary element a demonstration of direct impact on consumer welfare. However, even if it is a necessary element, it is argued that this test will not be easily administrable. In particular, for courts and competition authorities to assess the full effects of alleged unlawful exclusionary conduct on welfare will require an arduous assessment of complex economic evaluations and ultimately be counter-productive. These problems include limitations on both the ability of economists to measure accurately the net consumer welfare effects of particular conduct and the ability of judges to evaluate this evidence. ${ }^{52}$

While the test as a general balancing exercise presents some flexibility, the complexity of administering this test also means that firms and their advisors would find it difficult to determine at the outset whether specific conduct would constitute predatory pricing, especially under section $8(c)$. This will have a potentially chilling effect on pro-competitive conduct and reduce consumer welfare. A further consequence of a standard under which every action of a dominant firm must be scrutinised for net consumer-welfare effects threatens to chill a dominant firm's incentives to engage in procompetitive conduct out of fear of investigation, litigation, or even mistaken liability - again, potentially harming consumer welfare.

\section{STRATEGIC ECONOMIC THEORIES OF PREDATORY PRICING}

Traditionally, predation claims arise in the context of aggressive pricing. A large firm is alleged to have cut prices below cost to drive out its smaller rivals intending later to raise prices and exploit consumers. Heading 5.1 discusses the criticism of the traditional theory of predation. While most antitrust literature on predation has focused on static cost-based tests of whether price is below some relevant measure of cost, the economic literature has developed a range of theories of predation that seek to show that the dynamics of predatory behaviour and its motivations could be a

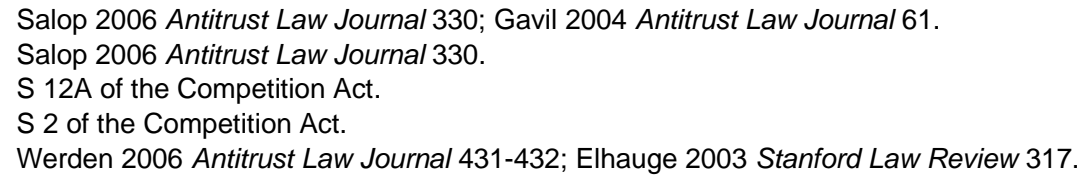


rational strategy in certain factual settings. Heading 5.2 briefly reviews some of those theories. ${ }^{53}$ Predation can also take place using means other than price. Claims for non-pricing conduct may found a claim for predatory behaviour under section 8(c). Accordingly, heading 5.3 discusses some of the main strategies concerning non-price predatory conduct.

\section{Criticisms of the traditional theory of predation}

In his 1958 article, McGee analysed the 1911 Standard Oil decision, ${ }^{54}$ a case long held up as the classic example of predation. McGee was sceptical of predation. He claimed that the Standard Oil Company achieved its dominant position through "voluntary" merger and acquisition, buying out refining competitors at or above market prices. He found little indication in the trial record that predation had occurred.

McGee argued that a predatory strategy by a large firm would lead to large losses. In particular, due to their large market shares, the substantial revenues lost by a dominant firm when engaging in predatory pricing would be unlikely to be worthwhile. Also, recoupment of losses is unlikely as the gains from higher prices, if any, are likely to be short-lived because higher prices provide a strong incentive for entry (or re-entry). Predation might not lead to exit because investors might be willing to provide loans under the expectation that the prey's losses are only temporary. Cheaper alternatives might also be available, since predation must be more profitable than alternative strategies, such as merging with the prey. This theory suggested that predatory pricing is irrational and unlikely to be observed. The question thus remained, is predation feasible at all? ${ }^{55}$

\section{Modern theories of predation}

Game theoretical models of predation represent a departure from the static framework of perfect information. New theories rely on a dynamic world of imperfect and asymmetric information in which predatory pricing can be a profit-maximising strategy. Firms act strategically to modify competitors' expectations of profitability. Under this analysis, the predator seeks to influence the expectations of an existing competitor, a potential competitor, and even the prey's creditors, to convince the competitor that continued competition or future entry into the market would be unprofitable.

53 Headings 5.1 and 5.2 rely heavily on the research done by McGee ("Predatory Price Cutting: The Standard Oil Case" 19581 Journal of Law and Economics 137), Koller II ("The Myth of Predatory Pricing: An Empirical Study" 19714 Antitrust Law \& Economics Review 105), Bork (The Antitrust Paradox: A Policy at War With Itself (1978)), Easterbrook "Predatory Strategies and Counterstrategies" 198148 University of Chicago Law Review 263), and Bolton, Brodley and Riordan ("Predatory Pricing: Strategic Theory and Legal Policy" 200088 Geo Law Journal 223).

54 Standard Oil Co. of New Jersey v. United States (1911) 221 U.S. 1.

55 It must be stated that in a re-examination of the Standard Oil case, the case on which McGee had primarily relied in rejecting the logic of predation, it was found that Standard had in fact used predatory tactics, although not necessarily predatory pricing, against its rivals, but in a far subtler way than McGee had imagined. In this regard, see Granitz and Klein "Monopolization by 'Raising Rivals' Costs': The Standard Oil Case" 199639 The Journal of Law and Economics 1. 
Developing the strategic approach to predatory pricing, economists have formulated several coherent theories. These theories, which include financial market predation and various signalling strategies, demonstrate that predatory pricing is a rational, profit-maximising strategy. While the formal economic proof of the theories is complex, their intuitions are simply described below.

\section{Financial market predation}

Under this theory, the prey is dependent upon outside funding to survive predatory conditions and the predator is fully aware of that. The predatory strategy involves the predator reducing its prices below cost in order to reduce the profitability of its competitors. The competitors' investors view this decrease in profitability as a sign of limited prospects in this market and decide to decrease or withdraw financial support. The model relies on capital market imperfections. Due to the asymmetry of information between the firms and capital markets, investors are unable to distinguish between predatory pricing and poor performance by managers of the preyed-upon firm. Thus, contrary to McGee's view, the prey may not be able to obtain capital readily under predatory conditions and may be forced to exit.

\section{Signalling theories of predation}

Signalling models of predation rely on imperfect and asymmetric information between predator and its competitors (prey or future entrants). To the extent that the predator is better informed than its competitors about its own costs and market conditions, its actions can influence its competitors' expectations regarding future profits therefore leading to exit (or discouraging entry). The informed predator sells at low price to mislead its competitor into believing that market conditions are unfavourable. Recoupment of losses is likely to materialise, thus making predatory pricing profitable. Signalling theories include reputation effect, test-market and signal-jamming, and cost signalling.

\section{(i) Reputation models of predation}

Reputation effects may arise in circumstances where the predator sells in multiple markets or within one market in consecutive time periods. The predatory strategy involves the dominant firm establishing a reputation for predatory pricing based on some perceived advantage. The potential for predatory behaviour relies on information being imperfect. The predator takes advantage of its competitors' uncertainty and prices aggressively to make them believe it is a strong competitor. The predator's reputation for aggressive pricing behaviour might deter entry or encourage exit not only in the market where predation takes place but potentially in other markets where the predator operates. As long as the predator's conduct is observed, this reputation effect can extend within the market across periods, across product markets and across geographic markets. 


\section{(ii) Cost-signalling models of predation}

Under this theory, the predator increases its volume and reduces prices below cost. The predator signals to its competitors that it is a low-cost, rather than high-cost, supplier even though it may have no cost advantage. The competitors are not certain about the predator's true cost structure and will choose to exit the market or not enter the market if they believe the dominant firm is a low-cost supplier.

\section{(iii) Demand-signalling models of predation}

Under this theory, the prey is attempting to ascertain demand for its product, either a new product or its product in a new geographic market. Two predatory strategies may be relevant. First, the dominant firm responds by offering secret discounts, thus leading the entrant to believe that demand is low ("test-market predation") and/or, secondly, the dominant firm openly reduces its price below cost to prevent the prey from identifying true market conditions ("signal-jamming predation"). By purporting a situation of weak demand, the predator's actions may deter entry and/or expansion.

\section{Predation for mergers}

Similar to other signalling models, the dominant firm acts strategically in order to eliminate its competitors. However, its goal is not to induce exit but rather to improve the terms that the prey will accept in a takeover. The predatory strategy involves the dominant firm choosing to price aggressively to modify the beliefs about future profits by competitors, who, faced with perceived unfavourable conditions, might agree to sell out at low prices.

\section{Alternative theories of predation}

\section{Predatory capacity expansion}

Predation may also occur through excess capacity. ${ }^{56}$ In a predation analysis, the relevant period in which a firm's conduct is undertaken may crucially affect whether a firm's behaviour may be viewed as having a legitimate business purpose. Thus, a longer-term approach is particularly important for the investment decisions of firms.

Consider the following situation: in period $T_{1}$, the incumbent has a capacity of 100 units. In period $\mathrm{T}_{2}$, the entrant appears on the horizon and the incumbent realises that the entrant plans to enter the market against the incumbent in period $T_{4}$. Therefore, in period $T_{3}$ the incumbent increases its production by another 100 units to a total capacity of 200 units. Nonetheless, in period $\mathrm{T}_{4}$ the entrant enters. There is now excess capacity in the market.

6 Williamson "Predatory Pricing: A Strategic and Welfare Analysis" 197787 Yale Law Journal 284; Bishop and Walker The Economics of EC Competition Law 319; Joskow and Klevorick "A Framework for Analyzing Predatory Pricing Policy" 1979 89(2) The Yale Law Journal 213. 
The extra capacity is unavoidably sunk and price falls to variable cost, which is significantly below average total cost. The additional investment in $T_{3}$ was clearly unprofitable. This sort of scenario poses difficult questions. Although on an average variable cost standard, the pricing by the incumbent in $T_{4}$ is not predatory, the capacity expansion by the incumbent in $T_{3}$ might be deemed a predatory output expansion to the extent that, viewed from that point in time, when the cost of capacity was not yet committed, the incremental revenue was not expected to cover incremental cost.

A slight variation of the excess capacity argument is to say ${ }^{57}$ that excess capacity lowers the marginal cost of increasing output and so lowers the cost of responding to entry aggressively by increasing output. By lowering this cost, it makes a predatory increase in output post-entry cheaper and thus more likely. Observing the excess capacity, the potential entrant concludes that entry would be met by a very aggressive response and so does not enter. Excess capacity coupled with a reputation for predation may be a very effective form of entry deterrence under this strategy.

\section{Scheduling, advertising, brand proliferation and predatory product announcements}

Predatory scheduling involves scheduling transport services to arrive just before the competitor's service so as to reduce the competitor's demand, which leads to no consumer benefit even in the short run. ${ }^{58}$ Alternatively, other mechanisms relate to scheduling free services or increased services so that an entrant cannot profitably run a service.

In a predatory advertising strategy, the predator increases advertising spend above the profit-maximising level in order to make new entry harder.

Entry deterrence can also take the form of predatory product variety or brand proliferation. ${ }^{59}$ This strategy involves introducing so many brands that a new entrant would find it very difficult to find a profitable niche, especially when coupled with intense advertising or a reputation for not repositioning brands in response to entry, such that there is no "product space" left for other firms to introduce new brands.

Predatory product announcements can occur in markets characterised by continuous innovation. ${ }^{60}$ In these types of market, customers are concerned that if they buy a product it will soon be superseded by a superior product. Incumbents fearing entry from a new product are often known to preannounce a new improved version of their product (so-called "vapourware") to encourage customers to wait. This deters customers from buying from the potential entrant even if the new product from the incumbent turns out to be delayed.

57 Bishop and Walker The Economics of EC Competition Law 319.

58 See Chester City Council v Arriva [2007] EWHC 1373 (Ch) and the UK OFT Decision No CA98/01/2008, Abuse of a dominant position by Cardiff Bus (Case CE/5281/04), 18 November 2008.

59 Bishop and Walker The Economics of EC Competition Law 319.

60 See Bishop and Walker The Economics of EC Competition Law 320-322 in connection with predatory behaviour in high-tech industries. 


\section{CONCLUSION}

If the dominance threshold is met, the abuse analysis should be carried out in a way that integrates the findings of the market power analysis. Allegations of predatory pricing illustrate the point. To the uninitiated consumer, predatory pricing can seem like normal low-cost pricing forming part of normal competition. For the competitors in the market, a number of commercial justifications exist for why they price below their incremental costs, which mostly have no material adverse effects, especially for consumers. However, predatory pricing is an exclusionary abuse that indirectly causes loss to consumer welfare. Without independent evidence of market power, there would be no justifiable reason for competition policy scrutiny of such pricing. When there is independent evidence showing market power amounting to dominance, then further scrutiny makes sense.

The Act's definition of an exclusionary act as a formulation of the meaning of abuse is hard to follow. So too are the formulations under EU competition law. Although the definitions of an "exclusionary act" and an "abuse" are different in detail, both are intended to discriminate between conduct that is anti-competitive and that which is pro-competitive. The main focus of an unlawful exclusionary act is on harm to competition (or the competitive process), as opposed to harm to competitors, and thereby harm to consumers. Mere harm to competitors, without harm to the competitive process is not enough to constitute an unlawful exclusionary act. However, the definition does not present the underlying principles by reference to which conduct that distorts and harms competition can be distinguished from normal competition on the merits. Therefore, the more important consideration should be the weighing of the effects of the act under section $8(c)$ or $(d)$, whichever is appropriate, in order to determine whether the conduct in question is pro-competitive or anti-competitive, and then to consider what consequences flow from that act if it is shown to be "exclusionary".

Competitive and exclusionary conduct can look alike, and the same conduct can have both beneficial and exclusionary effects. This makes it hard to distinguish conduct that should be deemed unlawful from conduct that should not. The two main standards used to identify exclusionary conduct in the context of predatory pricing are the profit-sacrifice test and the equally-efficient-competitor test. The no-economic-sense test, as a variant of the profit-sacrifice test, and the consumer-welfare test have also been developed for these purposes.

In the context of the profit-sacrifice test, for example, the inquiry will be whether the strategy of lowering price in the short run was profitable compared to a feasible, less exclusionary strategy that could have been considered by the firm at the time. In this format as a test for section 8 liability, the test raises serious concerns. While for certain types of pricing abuse, like predatory pricing, it may serve as a useful indicator, the test cannot on its own be used to identify unlawful exclusionary conduct and thereby distinguish it from competition that has a legitimate business purpose. Similarly, it is suggested that the no-economic-sense test by itself is not sufficient to constitute a necessary condition for liability in all section 8 
cases. However, combining the profit-sacrifice test with the no-economicsense test may sometimes be useful in identifying certain exclusionary conduct, especially in the context of predatory pricing. The equally-efficientcompetitor test revolves around the determination of whether an equally efficient competitor could have made a profit by charging the same price. A firm would thus be able to pass the equally-efficient-competitor test but fail the profit-sacrifice test. Given the open-ended nature of the consumerwelfare test and the inherent uncertainty for businesses in predicting its outcome, it is doubtful that it should be the general test for analysing conduct under section 8. Although consumer welfare should remain the goal of enforcement efforts, that objective is likely to be better served by a standard that takes better account of administrative costs and the benefits of dynamic competition for economic growth.

Ultimately, it is suggested that there is no single test that should be used to define anti-competitive conduct for purposes of identifying exclusionary conduct and hence for a finding of liability under section 8 . Although many of the proposed tests have virtues, they also have flaws. This suggests that none currently works well in all situations. Thus, different types of conduct warrant different tests, depending upon, among other things: the scope of harm implicated by the practice; the relative costs of false positives, false negatives and enforcement; the ease of application; and other administrability concerns. An important goal for any test should be to identify conduct that harms competition while enabling firms effectively to evaluate the legality of their conduct before it is undertaken. In applying legal standards, courts should determine whether the conduct at issue warrants employing a conduct-specific test.

Until fairly recently, economic theories were unable to show by way of rigorous explanation how below-cost pricing could be rational business behaviour for a firm with market power. The courts fell back on known economic theory - static analysis in a world of perfect information, which the theory as well as empirical studies appeared to support. However, once the issues of asymmetric information and uncertainty are coherently reinserted into the simplest of economic models that assume these issues away, there appears to be ample scope for rational, and hence credible, threats of below-cost pricing. Strategic theories of modern economics can now explain when predation can be rational and have cast new light on the traditional theories of predatory pricing. Similarly, there has also been an increase in the identification and development of credible non-pricing strategies of predation. 